$\left(\begin{array}{lcrr}\text { Jpn. } & \text { J. } & \text { Hosp } & \text { Pharm. } \\ \text { 技 } & \text { 術 } & \text { 告 } \\ \text { 22(2) } & 206-215 & (1996)\end{array}\right)$

\title{
逐次試験法による再封可能容器の安全蓋の小児安全性評価
}

日高正人*, 渡辺 敦, 杉原正泰

東京女子医科大学病院薬剤部†

\section{Estimation of the Child Resistant Characteristics of Reclosable Packagings of Safty Closure by Sequential Test Method}

\author{
MASATO HIDAKA*, ATSUSHI WATANABE and MASAYASU SUGIHARA \\ Pharmaceutical Department, Tokyo Women's Medical College $†$
}

\author{
$\left(\begin{array}{lc}\text { Received October 3, } & 1995 \\ \text { Accepted February 21, } & 1996\end{array}\right)$
}

\begin{abstract}
The required forces for opening the safety closures of three reclosable packagings were measured at initial and after 60 opening and closing, and child resistant characteristics of those packagings were estimated by sequential test method, which reduces test subjects without changing the statistical parameters while permitting the same prediction accuracy with the PPPA (Poison Prevention Packaging Act) test method. As the results of the sequential tests, these packagings were statistically confirmed as child resistant materials under given conditions.

Trials had shown that people in the age group over 61 had not great difficulty in opening child resistant packagings. Then it seemed that there was no need for the age group $(61-65$ years $)$ to be tested specially.
\end{abstract}

Key words — child resistant characteristic, reclosable packaging, safety closure, sequential test, the elderly people

\section{緒訔}

小児の誤飲による中毒事故は多く，日本中毒情 報センターへの中毒に関する問い合わせの約 $80 \%$ が 5 歳未満の幼小览に関する問い合わせであると 報告されている ${ }^{1)}$. 医薬品がその原因物質とな ることも多く，医薬品の幼小児に対する中毒の防 止対策の必要性が叫ばれている。アメリカにおい ては，1970年にいち早く毒性容器防止法（PPPA：

$\dagger$ 東京都新宿区河田町8-1；8-1, Kawada-cho, Shinjuku-ku, Tokyo, 162 Japan
Poison Prevention Packaging Act）を制定し2,3), 危 険物質に対し CRP（Child Resistant Package：小览 用安全容器）が義務づけられている。CRPは, 5 歳以下の小児が, ある一定時間内に容器を開 け，中毒量までの分量を取り出すのが困難である が，一方大人には開けやすい包装であると定義さ れている ${ }^{4,5)}$.

ところで，CRPの基準設定の背景や内容など については最初に導入されたアメリカのPPPAの 影響が大きい( ${ }^{6}$. PPPAの基準内容には, CRPの 試験方法と判定基準，適用除外基準などが定めら 
れており，またCRPに関連する基本的な性能， 品質の標準設定，標準分類および包装された製品 の価值（機能）を保証するための基準は，ASTM (American Society Testing and Materials) 規格 （ASTM-D3469～3481）に設定されている.

さらに医薬品に関する内容は, USP（アメリカ 薬局方) 22版に小児安全包装(Packaging Child Safety)に関する事項が収載されている. 現在, CRPに関する規格，規制を有する国は，アメリ カ, イギリス, カナダ，オーストラリア，ドイ ツ, フランスの 6 か国の他，オーストリア，オラ ンダ，スウェーデンなどがあり, ISO(International Organization for Standardization: 国際標準化機 構）規格を含めるとかなりの規格基準が存在して いる.

各々の規格基準を比較してみると, CRPの適 用範冊では, SP (Strip Package) やPTP (Press Through Package) などの NR-CRP（Non-reclosable Package：再封不可能な包装）については，イギ リス，オーストラリア，およびISO 規格では除 外されている。 また，ドイツやフランスでは， 61 〜65歳の高齢者は CRP を開けにくいということ から成人試験パネルに高齢者試験が規定されてい るし, 試験方法として, PPPAでは，小児試験 200 名, 成人試験 100 名の一括テストであるのに対 して，ドイッ，フランス，イギリスおよびISO では逐次試験の方向へ移行しつつあるようであ る7).

本研究では, CRPのタイプとして,スナッ プ，プッシュアンドターンおよびスクイズアンド ターン型に分類される 3 種の CRPについて, ASTMの方法に準拠した機械を用いた開封力試 験を行った。さらにISO 規格案に準拠した幼児 および成人による開封・閉封試験を行い, 逐次試 験法を用いて小児安全性を検討した。

\section{実 験 の 部}

\section{1. 試料}

試験に使用した試料 No. 1 から試料 No. 3 まで
のCRPは，1） スナップ, 2 ）プッシュアンド夕 ーン, 3 ) スクイズアンドターンであり，その構 造を図 1 に示した。
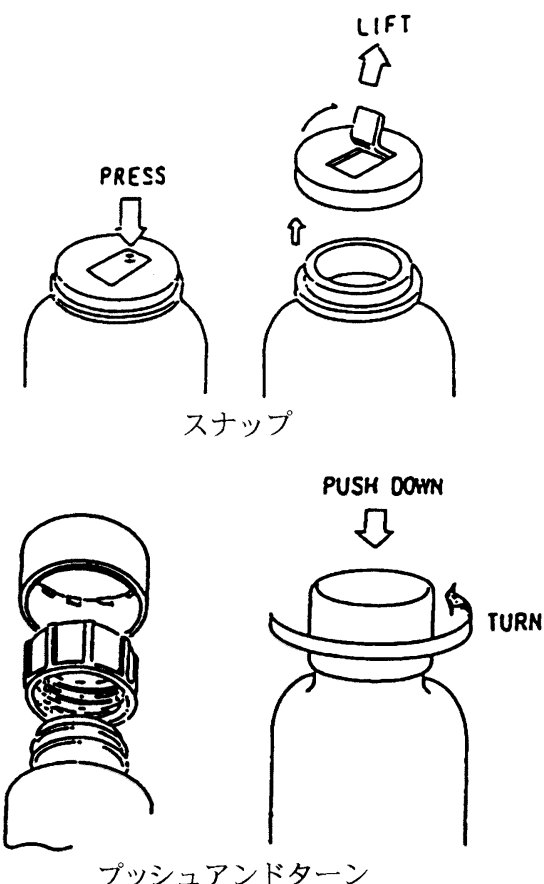

\section{TURA}
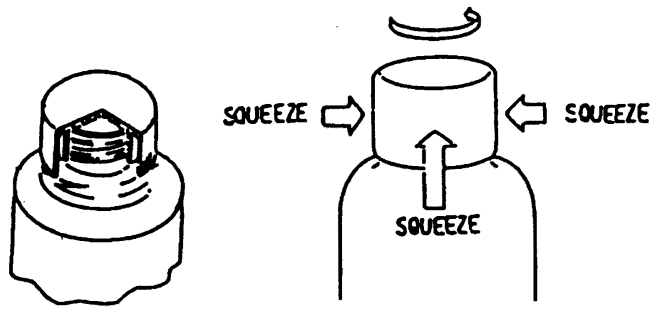

スクイズアンドターン

図 1。試験に使用したCRP の構造

試料 No. 1 および試料 No. 3 は, アメリカおよ びイギリスで実際に家庭用化学製品に使用されて いる CRP で，両国の CRP 規格基準にいずれも合 格した容器である。また試料 No. 2 は，我々が開 発し，既にふたを開けるためのトルク值の経時変 化や透湿性を報告した容器である ${ }^{8)}$.

\section{CRP の開封力試験}

各々の試料容器について10本を選択し，初期と 
60回開閉後，その10本についてそれぞれ 3 回また は 5 回測定し, 平均値を求めた.

\section{1 ) 試料 No. 1}

ASTM-D3840-81の規格を準用して，パッケー ジを開けるのに必要な下向きの力の測定を行っ た。ふたの表示された箇所に力を加えるのに必要 な荷重ジグはASTMではふたの設計コンセプト に従うものとしている. 本試料についは図 2 に示 すような直径 $8 \mathrm{~mm}$ で接触端が $\mathrm{R} 4$ が適当であっ た.

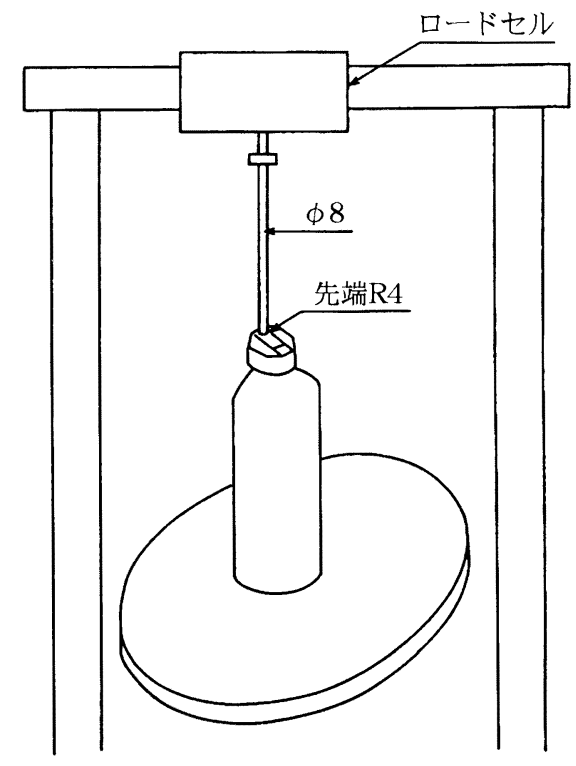

図 2.スナップ型の試験方法

\section{2) 試料 No. 2}

ASTM-D3471-82の規格を準用して，ふたのリ ムーバルラグをかみ合わせて固定するのに必要な 上からの力の測定と, D3472-81の規格を準用し て，逆ラチェットトルク（ふたを時計と反対方向 に回転させる際に生じるトルク）の測定を行っ た.

図 3 に示したような装置を用いて，ふたと共に 自由に動くリニアベアリングを通したロッドに荷 重を $1 \mathrm{lb}$ (ポンド単位) ずつ加え，トルクテス夕 ーでラグエンゲージメントが起きたときの全荷重 を $\mathrm{lb}$ 単位で記録した。

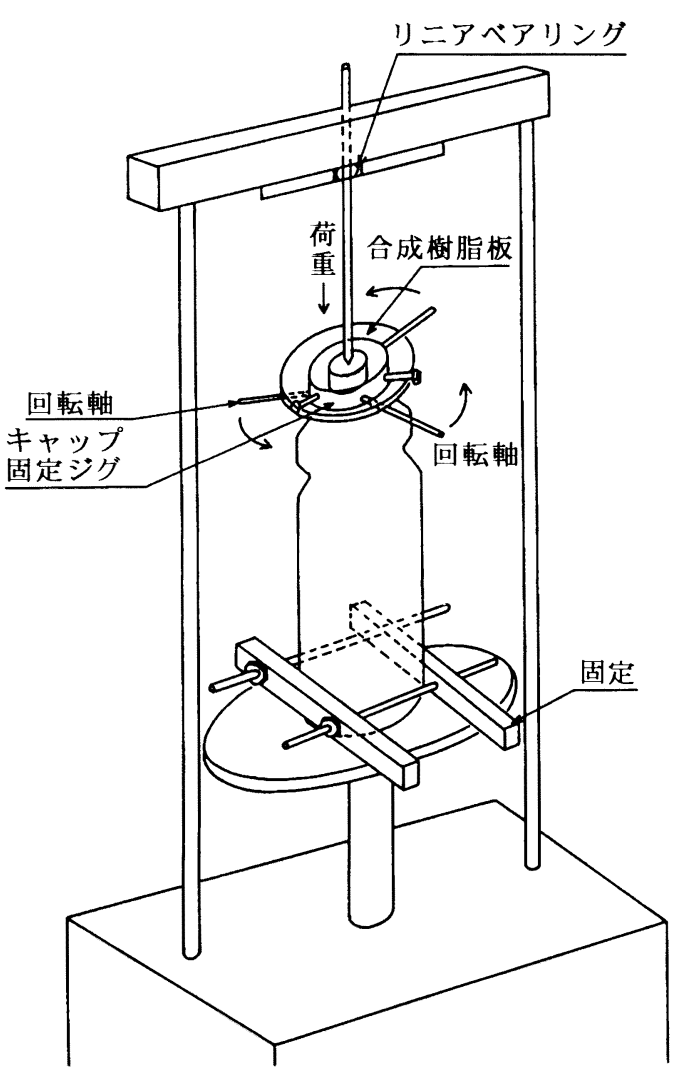

図 3.プッシュアンドターン型の試験方法

\section{3) 試料 No. 3}

ASTMには試験規格がないので，図 4 に示し たような装置を制作し測定した。この方式はふた の縁の対称の位置に力を加える指定箇所があり， ここをスクイズ（つかむ）しながら回転させて開 封する方式である．つかむ箇所は直径 $10 \mathrm{~mm} く ら$ いであり，親指と人差し指でつかむ力は $2 \mathrm{kgf} \sim$ $5 \mathrm{kgf}$ であるから, 試験は $1 \mathrm{kgf} \sim 6 \mathrm{kgf}$ の範囲で

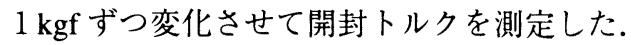

\section{CRPの幼児および成人による開封・閉封試}

験

幼児, 小児被験者の人数確保の問題点から,

2.の結果を踏まえ, 試験に使用する CRPの試 験順位を開封しやすいと思われる順（試料 No. 2, 試料 No. 1, 試料 No. 3 ）に決定した. 


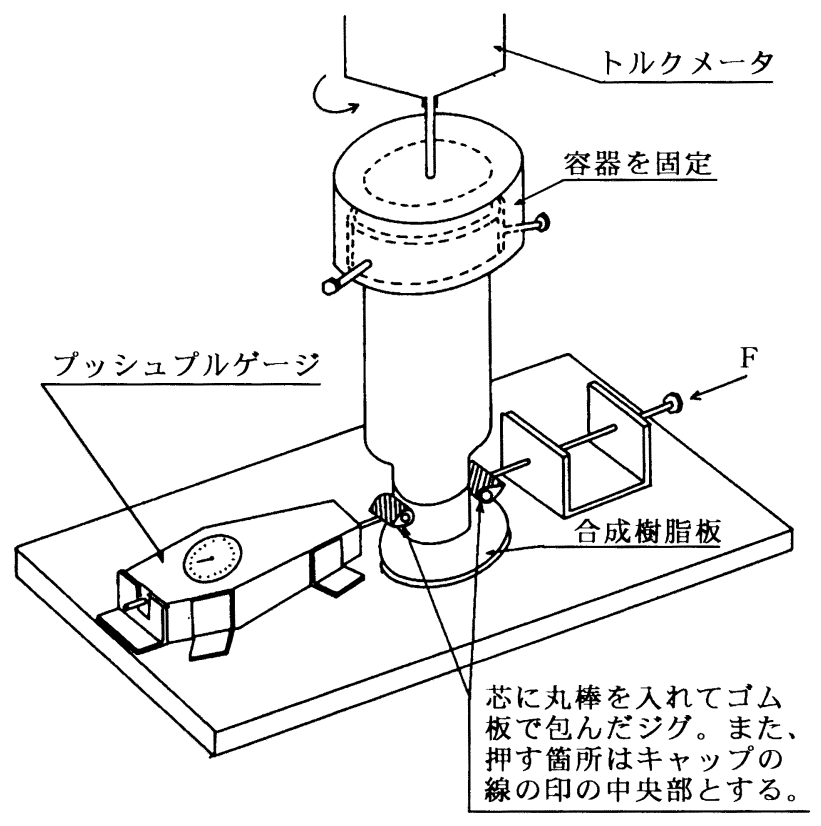

図 4.スクイズアンドターン型の試験方法

\section{1 ）幼児の試験方法と基準}

ISO による幼児試験の基準は，年齢が42力月か ら51カ月の範囲の健全な幼児を被験者としている が，本試験では52力月以上84カ月以下の幼児につ いても被験者とした。また，適否の判定方法も， 少人数で判定が可能である逐次試験 ${ }^{9}$ を採用し た.この試験法は, 合格品質水準 (AQL; Acceptable Quality Level) および限界品質（品質 不合格水準) (RQL; Rejectable Quality Level) の 統計的要素が PPPA の試験方法と基本的に同じよ うになるように，判定基準を設定した図 5 に示す ようなチャートを用いて判定する点が特徴であ る.

評価方法は, 試験の被験者が所与の時間内に容 器を開けられなかった場合は，その前に印をつけ たマス目の寸ぐ右隣のマス目に印をつけ，逆に開 けられた場合はその前に印をつけたマス目のすぐ 上のマス目に印をつける形式で行う。一連の試験 の結果が最終的に「Limit I」以下におさまれば CRP として適合，「LimitII」を越える場合は不適 合となる。つまり, 実地指導前の 5 分間では開封
できない幼児が 30 人以上連続していれば適合，さ らに，実地指導後の 5 分間で 27 名以上が開封不可 能であれば，被験 CRP はCR 効果が認められ CRP として適合となる。この方法では被験者が 少人数で適否の判定が可能である.

\section{2 ）成人の試験方法と基準}

CRP は 5 歳以下の小児が開栓することが難し くて有害な内容物を摂取できなく，一方，一般の 成人の場合は開封に困難を伴わないように設計ま たは構成された包装を意味している。そのため図 6 に示すチャートを用いて，幼児における試験と 同様な逐次試験を試みたが，幼児の試験とは逆 に，成人試験では 35 人以上が連続して開封および 閉封可能であれば適合となる，年齢層は，18歳か ら65歳までの成人で総数50名を対象に実施した. 男女の割合は, $14: 36 て ゙$ ISOの規格(女性が70\%) より女性の割合が多い。

なお，幼览対象試験では最大200回の試験，あ るいは成人では最大 100 回の試験後の結果が 「Limit I」以下に収まらず，また「Limit II」を 越えない場合，適合とも不適合とも判定できない 
（実地指導前）

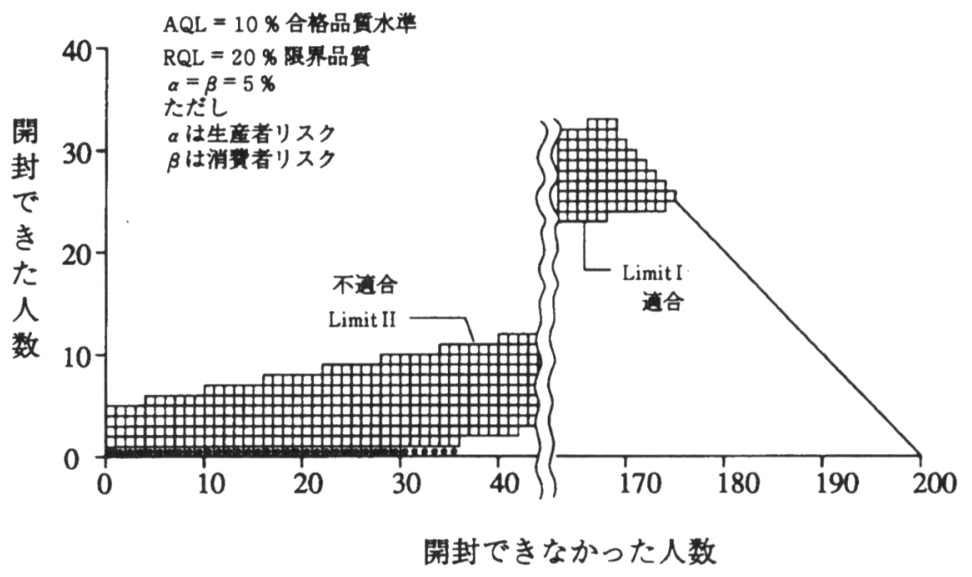

（実地指導後）

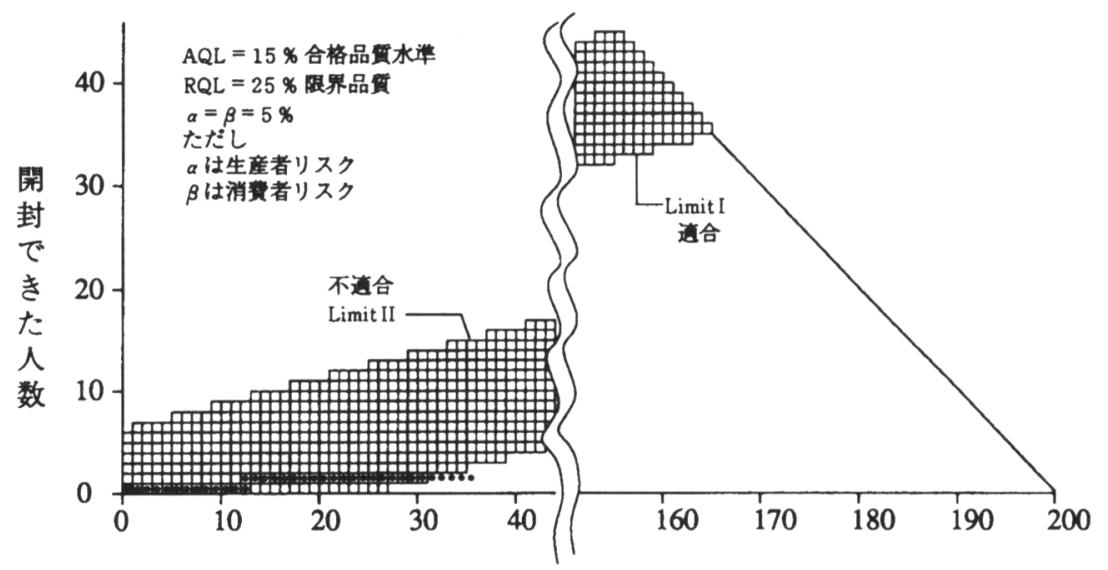

開封できなかった人数

図 5. 試料 No. 1 の開封実地指導前㧍よび指導後の幼児試験チャート

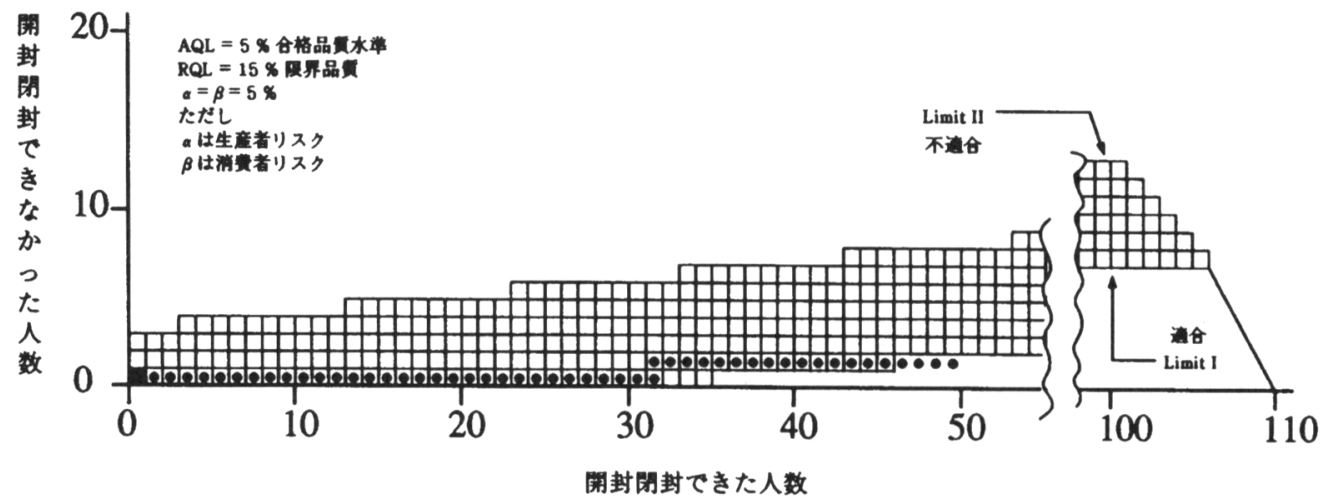

図 6. 試料 No. 1 の成人試験結果チャート 
ため，別に新たにPPPAの試験方法に基づいて評 価を行わなければならない.

\section{結果および考察}

\section{1. $\mathbf{C R P} の$ 物理試験結果}

\section{1) 試料 No. 1}

個々の試験結果を表 1 に示した。使用したジグ は, 直径 $8 \mathrm{~mm}$ でボールペンや鉛筆等の頭に相当 するくらいの大きさで，指頭の太い人，つめ幅の 広い人はエッジに当たって開けにくいことも考え られた。しかし，ふたを開けるのに必要な力は， 平均値で初期約 $3.5 \mathrm{kgf}, 60$ 回開閉後約 $3.0 \mathrm{kgf}$ と適 当な値と考えられた.

\section{2 ) 試料 No. 2}

個々の試験結果を表 2 に示した．開封に必要な 垂直荷重の平均值は, 初期で約 $4.81 \mathrm{~b}, 60$ 回後で 約 $4.6 \mathrm{lb}$ であった。 また，逆ラチェットトルクの 平均値は, 初期值, 60 回後の值共に約1.4kgf · $\mathrm{cm}$ であった。この逆ラチェットトルクは，ふた を開ける方向に加えられたトルクであり，この值 が大きいと開封してしまう可能性があるため, ASTM では測定することが重要であるとしてい る。ただし，最適な值がいくつかについての報告 はなく,この試料容器 No.2の值が適当かどうか は判断できなかったが, 他の市販のプッシュアン ドターン型の容器 8 種について試験的に測定を行
ったところ，約 $1.0 \mathrm{kgf} \cdot \mathrm{cm}$ から $2.5 \mathrm{kgf} \cdot \mathrm{cm}$ の範 囲の值を示した。

\section{3) 試料 No. 3}

スクイズカ $2 \mathrm{kgf}$ およ゙ $3 \mathrm{kgf}$ のきの開封し た数の割合および開封したときのトルク值の平均 値について、初期と60回後の試験結果を表 3 に示 した。

なお，スクイズカ $1 \mathrm{kgf}$ のを開封できた個数 はゼロで，また，スクイズ力 $3 \mathrm{kgf}$ 以上のときは すべて開封できたことから，スクイズカ $1 \mathrm{kgf}$ と $4 \mathrm{kgf}$ 以上のときの結果は省略した。このスクイ

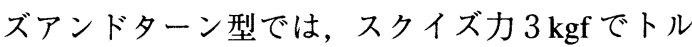
クが $4 \sim 5 \mathrm{kgf} \cdot \mathrm{cm}$ であれば開封されることにな る．逆に幼児が加えることのできるトルクが最大 $4 \mathrm{kgf} \cdot \mathrm{cm}$ であるとすると，スクイズ力 $3 \mathrm{kgf}$ 以 下であれば開封されないと考えられる.

このように 3 種の異なるタイプの CRP につい て，安全蓋の開封に必要な力を機械的に測定した が, 本研究では開封に必要な力と開封・非開封試 験の相関性を論じることはできなかった。開封に は，荷重やトルクなどの力以外に，キャップの大 きさ, 容器のボディの持ちやすさなどの因子も大 きく関わっていると思われ，機械による開封力測 定試験だけでは判断が下せないことが明らかにな った。

表 1. 試料 No. 1 の開封荷重

初期開封荷重（kg f)

\begin{tabular}{cccccc}
\hline 試料No & 1 回目 & 2 回目 & 3 回目 & $\overline{\mathrm{x}}$ & $\overline{\mathrm{X}}$ \\
\hline 1 & 3.40 & 3.23 & 3.18 & 3.27 & \\
2 & 3.01 & 2.99 & 2.84 & 2.95 & \\
3 & 3.12 & 2.87 & 2.84 & 2.94 & \\
4 & 2.95 & 2.99 & 3.00 & 2.98 & \\
5 & 2.86 & 2.85 & 2.88 & 2.86 & 3.518 \\
6 & 4.83 & 4.55 & 4.45 & 4.61 & \\
7 & 3.47 & 3.37 & 3.30 & 3.38 & \\
8 & 4.29 & 3.98 & 3.76 & 4.01 & \\
9 & 4.97 & 5.19 & 5.10 & 5.09 & \\
10 & 3.24 & 3.03 & 3.01 & 3.09 & \\
\hline
\end{tabular}

60回開閉後開封荷重（kg f)

\begin{tabular}{cccccc}
\hline 試料No & 1 回目 & 2 回目 & 3 回目 & $\overline{\mathrm{x}}$ & $\overline{\mathrm{X}}$ \\
\hline 1 & 3.24 & 3.18 & 3.15 & 3.19 & \\
2 & 2.94 & 2.66 & 2.60 & 2.73 & \\
3 & 2.32 & 2.24 & 2.20 & 2.25 & \\
4 & 2.88 & 2.76 & 2.69 & 2.78 & \\
5 & 2.20 & 2.14 & 2.09 & 2.14 & 2.994 \\
6 & 3.58 & 3.54 & 3.49 & 3.54 & \\
7 & 3.43 & 3.33 & 3.29 & 3.35 & \\
8 & 3.26 & 3.15 & 3.10 & 3.17 & \\
9 & 4.33 & 3.85 & 3.77 & 3.98 & \\
10 & 2.90 & 2.79 & 2.74 & 2.81 & \\
\hline
\end{tabular}


表 2. 試料 No. 2 の開封荷重および逆ラチェットトルク

初期開封荷重（lb）

\begin{tabular}{cccccc}
\hline 試料No & 1 回目 & 2 回目 & 3 回目 & $\overline{\mathrm{x}}$ & $\overline{\mathrm{X}}$ \\
\hline 1 & 5 & 5 & 5 & 5.0 & \\
2 & 4 & 3 & 4 & 3.7 & \\
3 & 5 & 4 & 4 & 4.3 & \\
4 & 5 & 5 & 4 & 4.7 & \\
5 & 5 & 5 & 5 & 5.0 & 4.77 \\
6 & 5 & 5 & 5 & 5.0 & \\
7 & 5 & 5 & 5 & 5.0 & \\
8 & 5 & 5 & 5 & 5.0 & \\
9 & 5 & 5 & 5 & 5.0 & \\
10 & 5 & 5 & 5 & 5.0 & \\
\hline
\end{tabular}

60回開閉後開封荷重（lb）

\begin{tabular}{cccccc}
\hline 試料No & 1 回目 & 2 回目 & 3 回目 & $\overline{\mathrm{x}}$ & $\overline{\mathrm{X}}$ \\
\hline 1 & 5 & 4 & 5 & 4.7 & \\
2 & 4 & 3 & 4 & 3.7 & \\
3 & 5 & 4 & 4 & 4.3 & \\
4 & 5 & 5 & 4 & 4.7 & \\
5 & 5 & 5 & 5 & 5.0 & 4.61 \\
6 & 5 & 4 & 5 & 4.7 & \\
7 & 5 & 5 & 5 & 5.0 & \\
8 & 5 & 5 & 5 & 5.0 & \\
9 & 5 & 4 & 4 & 4.3 & \\
10 & 5 & 4 & 5 & 4.7 & \\
\hline
\end{tabular}

初期逆ラチェットトルク $(\mathrm{kg} \mathrm{f} \cdot \mathrm{cm})$

\begin{tabular}{cccccccc}
\hline 試料No. & 1 回目 & 2 回目 & 3 回目 & 4 回目 & 5 回目 & $\overline{\mathrm{x}}$ & $\overline{\mathrm{X}}$ \\
\hline 1 & 1.42 & 1.30 & 1.48 & 1.23 & 1.38 & 1.362 & \\
2 & 1.20 & 1.40 & 1.32 & 1.36 & 1.44 & 1.344 & \\
3 & 1.39 & 1.52 & 1.39 & 1.32 & 1.31 & 1.386 & \\
4 & 1.35 & 1.30 & 1.40 & 1.37 & 1.45 & 1.374 & \\
5 & 1.48 & 1.20 & 1.39 & 1.30 & 1.31 & 1.300 & 1.396 \\
6 & 1.32 & 1.49 & 1.36 & 1.33 & 1.45 & 1.390 & \\
7 & 1.50 & 1.60 & 1.40 & 1.56 & 1.30 & 1.472 & \\
8 & 1.40 & 1.45 & 1.32 & 1.30 & 1.41 & 1.376 & \\
9 & 1.50 & 1.40 & 1.50 & 1.32 & 1.58 & 1.456 & \\
10 & 1.60 & 1.47 & 1.33 & 1.41 & 1.70 & 1.502 & \\
\hline
\end{tabular}

60 回開閉後逆ラチェットトルク $(\mathrm{kg} \mathrm{f} \cdot \mathrm{cm})$

\begin{tabular}{cccccccc}
\hline 試料No & 1 回目 & 2 回目 & 3 回目 & 4 回目 & 5 回目 & $\overline{\mathrm{x}}$ & $\overline{\mathrm{X}}$ \\
\hline 1 & 1.30 & 1.49 & 1.58 & 1.48 & 1.40 & 1.450 & \\
2 & 1.25 & 1.20 & 1.31 & 1.20 & 1.36 & 1.264 & \\
3 & 1.40 & 1.42 & 1.31 & 1.20 & 1.49 & 1.364 & \\
4 & 1.25 & 1.30 & 1.44 & 1.50 & 1.41 & 1.380 & \\
5 & 1.20 & 1.23 & 1.23 & 1.21 & 1.11 & 1.196 & 1.383 \\
6 & 1.28 & 1.33 & 1.30 & 1.36 & 1.29 & 1.312 & \\
7 & 1.70 & 1.61 & 1.32 & 1.29 & 1.60 & 1.504 & \\
8 & 1.35 & 1.34 & 1.40 & 1.50 & 1.31 & 1.380 & \\
9 & 1.68 & 1.31 & 1.62 & 1.61 & 1.40 & 1.524 & \\
10 & 1.32 & 1.51 & 1.43 & 1.42 & 1.53 & 1.458 & \\
\hline & & & & & & &
\end{tabular}

表 3 . 試料 No. 3 のスクイズ力および開封トルク

\begin{tabular}{|c|c|c|c|c|c|}
\hline & & 初 & 期 & 60 & 回 後 \\
\hline 試料 & スクイズカ & $\begin{array}{r}\text { 開封した数 } \\
\text { / 総数 }\end{array}$ & $\begin{array}{l}\text { 開封したとき } \\
\text { の平均トルク }\end{array}$ & $\begin{array}{r}\text { 開封した数 } \\
/ \text { 総数 }\end{array}$ & $\begin{array}{l}\text { 開封したとき } \\
\text { の平均トルク }\end{array}$ \\
\hline \multirow{2}{*}{ No. 3} & $2 \mathrm{~kg} \mathrm{f}$ & $20 / 30$ & $5.1 \mathrm{~kg} \mathrm{f} \cdot \mathrm{cm}$ & $13 / 30$ & $4.4 \mathrm{~kg} \mathrm{f} \cdot \mathrm{cm}$ \\
\hline & $3 \mathrm{~kg} \mathrm{f}$ & $30 / 30$ & $4.2 \mathrm{~kg} \mathrm{f} \cdot \mathrm{cm}$ & $30 / 30$ & $4.7 \mathrm{~kg} \mathrm{f} \cdot \mathrm{cm}$ \\
\hline
\end{tabular}

\section{CRP の開封・閉封試験}

\section{1) 試料 No. 1}

a. 幼児試験

逐次試験の結果を図 5 に示した. 36名中試験順 位13番目の幼児が実地指導後の開封に成功してい るが，規定の人数内でリミットI 以下でプロット が終了しており, 試料 No. 1 は幼児試験に適合で あった. 試料 No. 1 は他の夕イプと比較して CR
効果が低いと予想されたが，十分な CR 効果が認 められた。ほとんどの幼児は, 実地指導前には通 常のスクリューキャップと同様にふたを回す行動 が多く，ふた天面タブを押すことに気がつかなか った。また，実地指導後は，開封動作を示したに もかかわらず，指で天面ふたを押す動作を行うも のの指で押す位置が特定できず開封に至らないこ とがわかった. 
b. 成人試験

逐次試験の結果を図6に示した。32番目に, 62歳の女性が非開封・閉封者となったが, 最終的 にリミットI 以下でプロットが終了しており，試 料 No. 1 は成人試験に適合であった.

開封方法の説明書を読み，ほとんどの被験者が 開封・閉封できている。しかし，つめの長い女性 の被験者は開封しにくいようであった。また，開 封できなかった被験者は指の腹で押すため力が加
わらず開封に失敗していた。

\section{2 ) 試料 No. 2}

a. 幼児試験

逐次試験の結果を図 7 に示した。35名中試験順 位 23 番目の幼児が実地指導後の開封に成功してい るが, 規定の人数内でリミット I 以下でプロット が終了しており，試料 No. 2 は幼児試験に適合で あった。

試料 No. 2 は，容器自体が小さく，キャップを

（実地指導前）

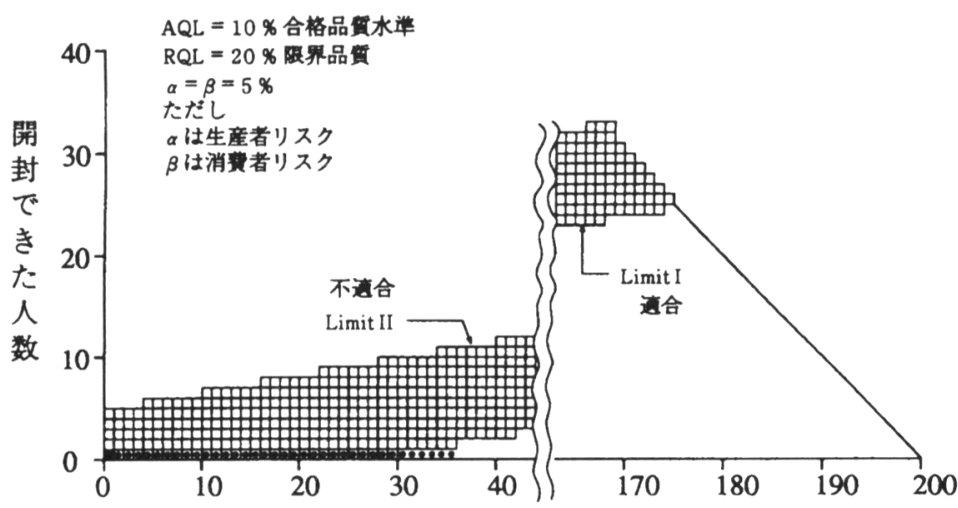

開封できなかった人数

（実地指導後）

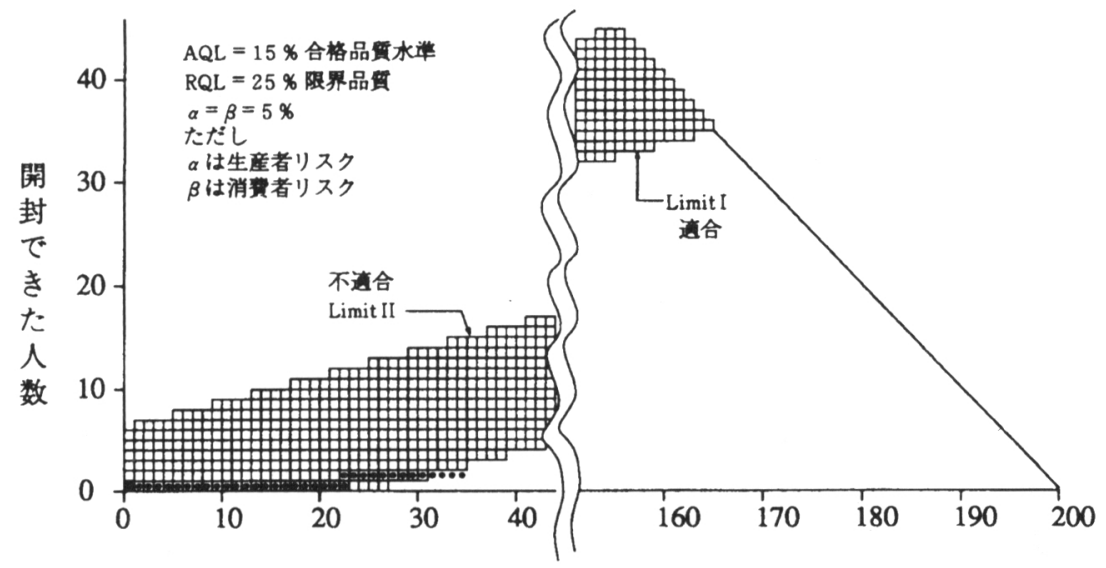

開封できなかった人数

図 7 . 試料 No. 2 の開封実地指導前および指導後の幼児試験チャート 
押す力も加わりにくいようで, 容器の大きさもプ ッシュアンドターン型の開封のしやすさに関係し ているようであった，また，実地指導の際，説明 者のキャップを押す動作は幼児には見分けがつか ず理解できないため, CRP としては優れた要素 を持っていると思われた。

b. 成人試験

逐次試験の結果を図 8 に示した。9，26，31お よび65番目に, 各々 25 歳女性, 63歳女性, 65歳女 性および50歳の女性が非開封・閉封者となった が，最終的にリミット I 以下でプロットが終了し ており，試料 No. 2 は成人試験に適合であった。

説明文の中の「押しながら」の進行形の動作の 必要性が理解できないケースが多く, 説明文の表 現方法の改良が必要と思われた。また，キャップ を垂直に押さないとねじに引っ掛ってしまうケー スも観察された。

\section{$3)$ 試料 No. 3}

a . 幼児試験

図には示していないが，試料 No. 3 における逐 次試験の結果においては, 41名中試験順位 28 番目 の幼児が実地指導前の開封に成功したものの, 規 定の人数内でリミット I 以下でプロットが終了し ており，実地指導後は開封者が皆無であったこと から試料 No. 3 は幼児試験に適合であった。実地 指導前に開封した例があったのは，偶然に指先が ふたの側面をスクイズし，力まかせにふたを回し ために開封したものと思われた。

スクイズアンドターン型は，ふたがフレキシブ
ルな要素を持つため, 偶然スクイズしたときや, スクイズしたふたの復元力が弱いものなど，容易 に開いてしまう可能性があり問題である。さら に，開封を繰り返すとキャップのつめが容器のス トッパに当たり，この部分は材質の厚みが薄いた め穴があきやすかったり，キャップのつめが変形 し本来の機能を果たさなくなるなどの問題も認め られた。

\section{b. 成人試験}

試料 No. 3 における逐次試験の結果, 図には示 していないが，32番目に，42歳の女性が非開封 · 閉封者となったものの，最終的にリミットI 以下 でプロットが終了しており，試料 No. 3 は成人試 験に適合であった。

説明文が理解できなくても力まかせで開けてし まう被験者が認められ，また逆にキャップのつめ が容器側のストップに食い込んでしまい開封でき なくなるケースも認られた。

以上の結果から，CRPの適合試験において被 験者が少人数ですむ逐次試験の有用性が確認され た。

一方，高齢者に関しては，ISO の審議過程にお いて，DP8317の段階では被試験者の中に65７0 歳が含まれていたものが，実施の難しさなどの理 由により削除された。しかし，ドイッでは61６5 歳の年齢層の人々は CRP の蓋の扱いに手こずる 者の数が明らかに増大することが観察され，実際 この種のパッケージングが使えないために，高齢 者にとっての必要条件や要求を満たさないことも

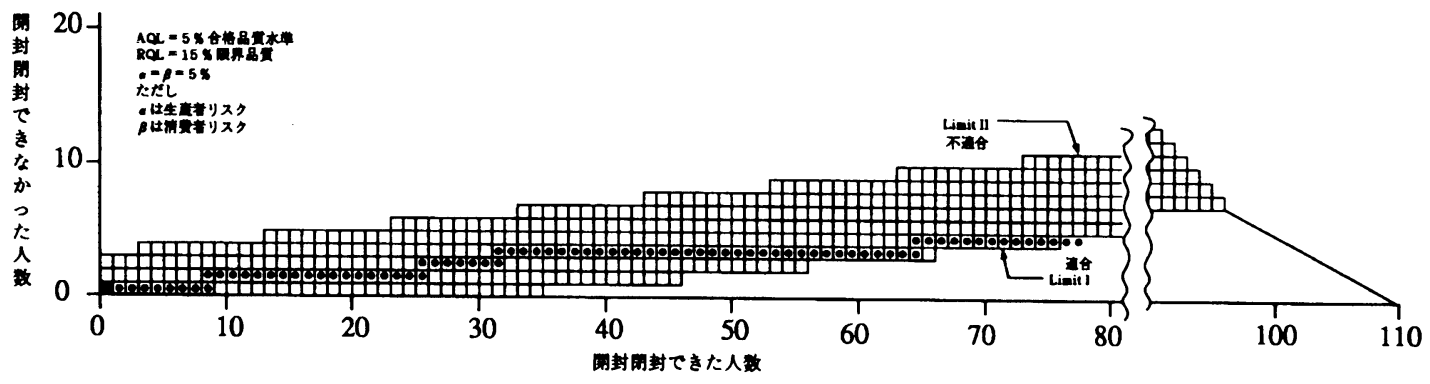

図 8. 試料 No. 2 の成人試験結果チャート 
ありうるため, 既に述べたように, 61〜 65歳の高 齢者対象の試験規定が設定されている.しかし, 日本における本研究において, 61歳以上の成人に ついては試験結果への影響はみられなかった。そ のため, 日本人についは, ドイツのように61歳以 上65歳以下という年齢範囲を特に設定する必要は ないと思われるが，高齢化社会を間近に控え，今 後65歳以上を対象とした試験法や高齢者に適する CRPの開発を検討していく必要があると思われ る.

さらに，本研究ではそれぞれの容器に対する被 験者の開封行動などの様子を観察することがで き, 説明文などの内容の問題点も推測することが できた。

日本では，まだCRPに関する規制がないが， 製造物責任 (Products Liability) 制度が施行され たことなどからも, 医薬品の幼坚中毒事故防止へ の包装・容器の責任は重く, 適切な CRP の設計 ・選択や患者への指導が薬剤師にも求められるも のと考えられ，CRPに関する研究は重要課題で あり，今後さらに検討を行いたいと考える。

\section{引用文献}

1) 新谷茂, 吉岡敏治, 後藤京子, 石沢淳子, 山田 容子, 磯村千鶴, 島津恵子, 中毒研究, 2 , 429-430 (1989).

2 ) Public Law 91-601 91st Congress S2162, Dec. (1970).

3 ) American Society for Testing and Meterials, STP 609 (1976).

4) 杉原正泰, 中毒研究, 5, 11-19 (1992).

5 ）杉原正泰, “医薬品の包装設計”, 杉原正泰編, 南山堂, 東京, 1984, pp. 107-124.

6 ）中林靖, 武田研究所報, 34, 569-585 (1975).

7 ）日高正人, 日本薬剤師会雑誌, 43, 1087-1096 (1991).

8 ） a）日高正人, 田中淑子, 渡辺敦, 杉原正泰, 病院薬学, 21, 115-123 (1995) ; b ) idem, ibid., 21, 124-130 (1995).

9） a ）杉原正泰, “続医薬品の開発 9巻 医薬品 の包装と容器 (II )”, 杉原正泰編, 廣川書店, 東京, 1991, pp. 403-420； b ) R. Gadeke and W. De Felice, Drugs Made in Germany, XXI, 3-17 (1978). 